\title{
MIKROENKAPSULASI Lactobacillus plantarum DENGAN BERBAGAI ENKAPSULAN PADA PENGERINGAN SEMPROT JUS JAMBU BIJI
}

\author{
[Microencapsulation of Lactobacillus plantarum in Guava Juice by \\ Spray Drying Using Several Types of Encapsulant] \\ Rina Ningtyas ${ }^{1)}$, Betty Sri Laksmi Jenie ${ }^{2) \star}$, dan Lilis Nuraida ${ }^{2,3)}$ \\ 1) Program Studi IImu Pangan, Institut Pertanian Bogor, Bogor \\ 2) Departemen IImu dan Teknologi Pangan, Fakultas Teknologi Pertanian, Institut Pertanian Bogor, Bogor \\ 3) SEAFAST Center, Institut Pertanian Bogor, Bogor
}

Diterima 21 April 2015 / Disetujui 27 November 2015

\begin{abstract}
Two strains of Lactobacillus plantarum (1\%) in guava juice were microencapculated by spray drying technique using several types of encapsulant, i.e. maltodextrin, maltodextrin in combination with other materials such as gum arabic, inulin, and galaktooligosakarida (GOS), with a ratio of 5:1. The objectives of this study were to compare the effect of encapsulation materials of Lactobacillus plantarum $2 C 12$ and Lactobacillus plantarum BSL on heat resistance $\left(50,60\right.$ and $70^{\circ} \mathrm{C}$, for $20 \mathrm{~min}$ ), survival at low pH (2.0), bile salts (0.5\%), and antimicrobial activity against Escherichia coli. Spray drying were performed at $120^{\circ} \mathrm{C}$ (inlet) and $70^{\circ} \mathrm{C}$ (outlet). The results showed that all types of encapsulated probiotics improved their resistances toward heat, low $\mathrm{pH}$ and bile salts as compared to free cells. The highest survival of probiotic cells was achieved by probiotic encapsulated with maltodextrin, and heated at $50^{\circ} \mathrm{C}$, with a protection of 2$3 \mathrm{Log} \mathrm{CFU} \mathrm{g}^{-1}$ as compared to free cells. Combination of maltodextrin and GOS (5:1) showed the highest protection toward low $\mathrm{pH}$ and bile salts, except for $\mathrm{L}$. plantarum BSL, the best encapsulant was maltodextrin. The antimicrobial activity of microencapsulated probiotic the cells did not change after the microencapsulation process. These results indicate that the guava powder probiotic can be developped by microencapsulation technique using maltodextrin or combination of maltodextrin and GOS with spray drying method.
\end{abstract}

Keywords: guava powder, Lactobacillus plantarum, microencapsulation, probiotic properties, spray drying

\begin{abstract}
ABSTRAK
Dua strain Lactobacillus plantarum (1\%) dalam sari buah jambu biji dimikroenkapsulasi dengan teknik pengeringan semprot menggunakan beberapa jenis bahan enkapsulan, meliputi maltodeks trin, kombinasi maltodekstrin dengan bahan enkapsulan lain seperti gum arab, inulin, dan galaktooligosakarida (GOS), dengan perbandingan 5:1. Tujuan dari penelitian ini adalah untuk membandingkan pengaruh jenis enkapsulan terhadap ketahanan probiotik Lactobacillus plantarum 2C12 dan Lactobacillus plantarum BSL terhadap panas $\left(50,60\right.$ dan $70^{\circ} \mathrm{C}, 20$ menit), $\mathrm{pH}$ rendah $(\mathrm{pH} 2,0)$ dan garam empedu $(0,5 \%)$, serta aktivitas antimikroba terhadap Escherichia coli. Proses pengeringan semprot dilakukan pada suhu $120^{\circ} \mathrm{C}$ (inlet) dan $70^{\circ} \mathrm{C}$ (outlet). Hasil penelitian menunjukkan semua bahan enkapsulan pada kedua strain mampu meningkatkan ketahanan probiotik terhadap panas, $\mathrm{pH}$ rendah dan garam empedu dibandingkan dengan sel bebas. Sintasan probiotik terbaik adalah pada suhu $50^{\circ} \mathrm{C}$, dengan bahan enkapsulan yang paling baik dalam melindungi sel probiotik terhadap panas adalah maltodekstrin, dengan perlindungan sebanyak 2-3 Log CFU g ${ }^{-1}$ lebih tinggi dibanding sel bebas (tanpa mikroenkapsulasi). Pada perlakuan dengan $\mathrm{pH}$ rendah dan garam empedu, bahan enkapsulan dengan proteksi yang paling baik adalah kombinasi maltodekstrin dan GOS (5:1) kecuali pada L. plantarum BSL, yang terbaik adalah maltodekstrin. Aktivitas antimikroba dari probiotik tidak mengalami perubahan setelah proses mikroenkapsulasi. Hasil ini mengusulkan pengembangan produk probiotik serbuk jambu biji menggunakan maltodekstrin atau maltodeks trin dan GOS dengan teknik mikroenkapsulasi pengering semprot.
\end{abstract}

Kata kunci: Lactobacillus plantarum, mikroenkapsulasi, pengeringan semprot, serbuk jambu biji, sifat fungsional

*Penulis Korespondensi:

E-mail: betty_jenie@yahoo.com 


\section{PENDAHULUAN}

Probiotik adalah mikroorganisme hidup yang jika dikonsumsi dalam jumlah yang cukup (> 7 Log CFU $\mathrm{g}^{-1}$ ) memberi manfaat kesehatan (FAO/WHO 2006). Genus Lactobacillus seperti $L$. acidophilus, $L$. rhamnosus, L. casei dan L. plantarum adalah bakteri probiotik yang umum ditambahkan pada pangan (Saad et al., 2013). Selama selang waktu dari pengolahan sampai pada konsumsi, probiotik pada produk pangan harus dapat dilindungi dari berbagai hal, seperti kondisi proses (suhu dan tekanan tinggi), desikasi apabila diaplikasikan untuk produk pangan kering, kondisi penyimpanan produk (matriks bahan pengemas) dan lingkungan (suhu, kelembaban, oksigen) serta degradasi pada saluran pencernaan, khususnya $\mathrm{pH}$ rendah di lambung (berkisar antara $\mathrm{pH} 2,5-3,5$ ) dan garam empedu di dalam usus halus (Manojlović et al., 2010).

Salah satu upaya dalam mempertahankan viabilitas dari probiotik adalah dengan menerapkan teknik mikroenkapsulasi. Mikroenkapsulasi merupakan suatu teknologi yang telah banyak dikembangkan untuk diaplikasikan dalam industri pangan sebagai upaya perlindungan terhadap sel bakteri (Borgogna et al., 2010). Pada teknik mikroenkapsulasi, metode pengeringan semprot direkomendasikan karena metode ini relatif murah dan dapat menampung larutan dalam volume yang besar (Mortazavian et al., 2007). Pada proses pengeringan semprot, efisiensi mikroenkapsulasi dapat diperoleh dengan pemilihan bahan enkapsulan dan kondisi pengeringan semprot yang optimal (Liu et al., 2004).

Serbuk buah probiotik adalah salah satu jenis produk probiotik berbahan dasar buah yang mulai dikembangkan dengan menerapkan teknik mikroenkapsulasi. Hernández-Carranza et al. (2014) mengembangkan serbuk pangan probiotik (asparagus, artichoke, jeruk dan kulit jeruk) menggunakan teknik mikroenkapsulasi dengan metode pengering semprot. Teknik mikroenkapsulasi yang diterapkan dilaporkan mampu mempertahankan populasi L. casei lebih dari $10^{7} \mathrm{CFU} \mathrm{g} \mathrm{g}^{-1}$ setelah penyimpanan 60 hari. Anekella dan Orsat (2013) telah mengembangkan produk probiotik berbentuk serbuk buah raspberi menggunakan metode yang sama dengan maltodekstrin sebagai bahan enkapsulan. Nualkaekul et al. (2012) juga mengembangkan produk serbuk buah probiotik dengan proses pencampuran kering serbuk buah (strawberi, delima, kismis hitam, cranberi) dan probiotik $L$. plantarum kering beku (freeze dried) serta penambahan inulin dan gum arab. Hasil penelitian menunjukkan produk serbuk buah merupakan pembawa yang sangat baik bagi sel probiotik $L$. plantarum dengan sintasan lebih dari $10^{6} \mathrm{CFU} \mathrm{\textrm {mL } ^ { - 1 }}$ selama penyimpanan 12 bulan.

Tujuan penelitian ini adalah untuk mengevaluasi penggunaan beberapa jenis bahan enkapsulan (maltodekstrin, dan campuran maltodekstrin dengan gum arab, inulin, dan GOS) yang dapat melindungi sel probiotik $L$. plantarum 2C12 dan L. plantarum BSL selama pengeringan semprot sari buah jambu biji. Evaluasi yang dilakukan terhadap produk serbuk jambu biji probiotik terenkapsulasi yakni sifat-sifat probiotik yang meliputi kemampuan ketahanan terhadap panas $(50,60$, dan $\left.70^{\circ} \mathrm{C}\right), \mathrm{pH}$ rendah $(\mathrm{pH} 2,0)$, dan garam empedu $(0,5 \%)$, serta sifat antimikroba terhadap $E$. coli ATCC 25922.

\section{BAHAN DAN METODE}

\section{Bahan}

Buah jambu biji merah matang (Pasar Dramaga Bogor), kultur probiotik L. plantarum 2C12 (Fakultas Peternakan IPB) dan L. plantarum BSL (Laboratorium Mikrobiologi Pangan Departemen ITP IPB), Bakteri patogen E. coli ATCC 25922 (Laboratorium Mikrobiologi Pangan Seafast Center IPB).

\section{Persiapan biomassa probiotik (Harmayani et al., 2001)}

Sebanyak satu ose probiotik ditumbuhkan pada media MRSB (Oxoid Ltd., England) kemudian diinkubasi selama 24 jam pada suhu $37^{\circ} \mathrm{C}$. Selanjutnya diambil sebanyak $10 \mathrm{~mL}$ untuk ditumbuhkan kembali dalam 1 liter MRSB (1:100). Biomassa dipanen menggunakan alat sentrifus (Himac CR 21G, Hitachi, Tokyo, Japan) pada 5000 g selama 20 menit pada $4^{\circ} \mathrm{C}$, kemudian dicuci dua kali menggunakan bufer fosfat (Merck, Germany) 0,1 M dengan cara disentrifugasi kembali (5000 g, 20 menit, $4^{\circ} \mathrm{C}$ ). Biomassa yang dihasilkan mengandung sel probiotik sekitar $1,0 \times 10^{11} \mathrm{CFU} \mathrm{\textrm {mL } ^ { - 1 }}$.

\section{Mikroenkapsulasi probiotik dalam sari jambu biji}

Sari buah Jambu biji dipersiapkan sebagai berikut. Buah matang dicuci dan dibilas dengan akuades steril. Selanjutnya, seluruh bagian buah (pulp, kulit dan biji) sebanyak $100 \mathrm{~g}$ dihancurkan dalam blender dengan penambahan akuades steril dalam dengan perbandingan 1:2 (b/v, buah/air), kemudian disaring menggunakan kain saring steril (Osorio et al., 2011).

Sari jambu biji dicampurkan dengan bahan enkapsulan dengan campuran 1:1 (b/b). Untuk perlakuan kombinasi maltodekstrin dengan bahan enkapsulan lain digunakan perbandingan 5:1 (b/b) untuk semua bahan enkapsulan (Osorio et al., 2011). Bahan enkapsulan yang digunakan adalah maltodekstrin (DE10-12, Cina), dan campuran maltodekstrin dengan gum arab (Houjin, Cina), inulin (Boneo-Orafti, Belgia), dan GOS (Jinao, Cina), masing-masing dengan perbandingan yang sama yaitu 5:1. Total padatan campuran sari jambu biji 
dengan bahan enkapsulan diatur hingga konsentrasi $38^{\circ}$ Brix dengan maltodekstrin. Selanjutnya campuran sari jambu biji dan bahan enkapsulan ditambah dengan biomassa probiotik $\left(10^{11} \mathrm{CFU} \mathrm{g}^{-1}\right)$ sebanyak $1 \%$ dan selanjutnya dikeringkan dalam alat pengering semprot (Buchi 190 Mini, Switzerland). Proses pengeringan semprot dilakukan pada suhu inlet $120^{\circ} \mathrm{C}$ dan outlet $70^{\circ} \mathrm{C}$, serta laju alir umpan adalah $485 \mathrm{~mL} / \mathrm{jam}$. Serbuk jambu biji probiotik terenkapsulasi (JBPE) dikemas dalam plastik polipropilen yang selanjutnya dimasukkan ke dalam wadah plastik (toples) untuk analisis lebih lanjut. Untuk mengetahui jenis bahan enkapsulan terbaik, maka setelah pengeringan semprot dilakukan pengukuran pengujian ketahanan probiotik pada produk serbuk jambu biji terhadap panas (suhu 50, 60 dan $\left.70^{\circ} \mathrm{C}\right), \mathrm{pH}$ rendah $(\mathrm{pH} 2,0)$ dan garam empedu $(0,5 \%)$, serta aktivitas antimikroba terhadap E. coli ATCC 25922.

\section{Pengujian ketahanan panas (Mandal et al., 2006)}

Pengujian ketahanan panas terhadap probiotik bebas dan terenkapsulasi dilakukan dengan menambahkan sampel probiotik masing-masing sebanyak $1 \mathrm{~g}$ ke dalam $9 \mathrm{~mL}$ akuades steril dan dihomogenisasi menggunakan vorteks (Vortex Genie 2, Scientific Industries Inc., USA). Selanjutnya larutan tersebut dipanaskan pada suhu 50, 60, dan $70^{\circ} \mathrm{C}$ dalam penangas air selama 20 menit, lalu didinginkan pada suhu ruang. Viabilitas probiotik setelah pemanasan dihitung dengan metode tuang menggunakan media MRSA (Oxoid Ltd., England) dan diinkubasi pada suhu $37^{\circ} \mathrm{C}$ selama 48 jam.

Ketahanan terhadap $\mathrm{pH}$ rendah $(\mathrm{pH} 2,0)$ dan garam empedu (0,5\%) (Modifikasi Nuraida et al. 2012 ${ }^{\mathrm{a}}$ )

Pengujian ketahanan probiotik terhadap $\mathrm{pH}$ rendah $(\mathrm{pH} 2,0)$ dilakukan sebagai berikut. Probiotik terenkapsulasi atau kultur probiotik bebas (tanpa enkapsulasi) diinokulasikan kedalam MRSB yang telah diasamkan dengan penambahan $\mathrm{HCl}$ (Merck KGaA, Germany) 0,1 M sampai $\mathrm{pH}$ media menjadi 2,0, dan diinkubasi pada $37^{\circ} \mathrm{C}$ selama 5 jam. Setelah diinkubasi, viabilitas probiotik selanjutnya dihitung dengan menggunakan metode yang sudah dijelaskan diatas pada pegujian ketahanan panas. Jumlah sel dari probiotik yang terenkapsulasi dibandingkan dengan sel probiotik bebas (tanpa enkapsulasi).

Pengujian ketahanan probiotik terhadap garam empedu $(0,5 \%)$ dilakukan sebagai berikut. Sebanyak $1 \mathrm{~g}$ probiotik terenkapsulasi atau kultur probiotik bebas diinokulasikan kedalam MRSB yang mengandung garam empedu (Difco, Canada) $(0,5 \%)$, dan diinkubasi pada suhu $37^{\circ} \mathrm{C}$ selama 5 jam. Selanjutnya kultur dihitung menggunakan media MRSA dengan teknik metode tuang seperti yang telah dijelaskan sebelumnya. Jumlah sel yang mampu bertahan terhadap garam empedu dari probiotik yang terenkapsulasi dibandingkan dengan sel probiotik bebas.

\section{Pengujian aktivitas antimikroba terhadap $E$. coli ATCC 25922 (Modifikasi Nuraida et al., 2012 ${ }^{\mathrm{b}}$ )}

Sebelum dilakukan pengujian, sel probiotik terenkapsulasi yang telah dilepaskan terlebih dahulu dari mikroenkapsulannya dengan natrium sitrat (Merck, Germany) 2\%. Uji aktivitas antimikroba probiotik terhadap bakteri patogen yakni $E$. coli ATCC 25922 dilakukan dengan metode kontak. Sebanyak 0,2 mL E. coli ATCC $25922\left(10^{5} \mathrm{CFU} \mathrm{\textrm {mL } ^ { - }}\right.$ $\left.{ }^{1}\right)$ dan $0,2 \mathrm{~mL}$ sel probiotik sebanyak $10^{8} \mathrm{CFU} \mathrm{mL}^{-1}$ diinokulasikan ke dalam $20 \mathrm{~mL}$ larutan susu skim (Sunlack, Malay) steril dalam erlenmeyer $50 \mathrm{~mL}$. Selanjutnya seluruh erlenmeyer tersebut dihomogenisasi secara manual hingga merata, lalu diinkubasi selama 24 jam pada suhu $37^{\circ} \mathrm{C}$. Jumlah sel E. coli ATCC 25922 yang tumbuh setelah dikontakkan dengan probiotik selanjutnya dihitung menggunakan media tumbuh EMBA (Oxoid Ltd., England). Hasilnya dibandingkan dengan jumlah sel E. coli ATCC 25922 yang tumbuh setelah dikontakkan dengan probiotik bebas.

\section{Analisis data}

Data jumlah sel probiotik (CFU $\mathrm{mL}^{-1}$ atau CFU $\mathrm{g}^{-1}$ ) yang diperoleh dari dua kali ulangan, dirataratakan dan dikonversi menjadi nilai Log CFU $\mathrm{mL}^{-1}$ atau CFU g ${ }^{-1}$. Data diolah menggunakan ANOVA dan uji beda nyata dianalisis dengan rancangan acak kelompok (RAK) menggunakan SPSS 16 dengan nilai signifikansi $P<0,05$.

\section{HASIL DAN PEMBAHASAN}

\section{Ketahanan panas probiotik terenkapsulasi ter- hadap panas}

Hasil pengujian ketahanan panas kedua strain probiotik L. plantarum $2 \mathrm{C} 12$ dan L. plantarum BSL dapat dilihat pada Tabel 1. Mikroenkapsulasi $L$. plantarum dengan teknik pengering semprot menggunakan beberapa jenis bahan enkapsulan mampu meningkatkan ketahanan panas sel probiotik dibandingkan sel probiotik bebas (tanpa penambahan enkapsulan). Hasil ini sesuai dengan Mandal et al. (2006) yang melaporkan kemampuan probiotik sel laktobasili yang dimikroenkapsulasi dengan alginat mengalami peningkatan kelangsungan hidup terhadap panas dibanding sel bebas tanpa mikroenkapsulasi. 
Tabel 1. Pengaruh jenis enkapsulan terhadap ketahanan panas probiotik pada serbuk JBPE

\begin{tabular}{|c|c|c|c|c|c|}
\hline \multirow[t]{2}{*}{ Probiotik } & \multirow{2}{*}{$\begin{array}{c}\text { Jenis } \\
\text { Enkapsulan }\end{array}$} & \multirow{2}{*}{$\begin{array}{l}\text { Jumlah Sel Awal } \\
\left(\text { Log CFU mL }{ }^{-1}\right)\end{array}$} & \multicolumn{3}{|c|}{$\begin{array}{l}\left.\text { Penurunan Jumlah Sel (Log CFU } \mathrm{mL}^{-1}\right) \text { setelah } \\
\text { Pemanasan }\end{array}$} \\
\hline & & & $50^{\circ} \mathrm{C}$ & $60^{\circ} \mathrm{C}$ & $70^{\circ} \mathrm{C}$ \\
\hline L. plantarum & Sel bebas & $8,00 \pm 0,00$ & $2,8 \pm 0,74^{\text {aal }}$ & $4,1 \pm 0,20^{\text {Dal }}$ & $6,6 \pm 0,0^{\text {cal }}$ \\
\hline \multirow[t]{4}{*}{$2 \mathrm{C} 12$} & $\begin{array}{l}\text { Maltodekstrin } \\
\text { (MD) }\end{array}$ & $7,6 \pm 0,09$ & $0,1 \pm 0,04^{\mathrm{ael}}$ & $2,1 \pm 0,12^{\mathrm{vel}}$ & $3,0 \pm 0,01^{\mathrm{cel}}$ \\
\hline & $\mathrm{MD}+\mathrm{Gum}$ Arab & $7,8 \pm 0,07$ & $0,7 \pm 0,23^{\text {aाı }}$ & $2,4 \pm 0,13^{\mathrm{DII}}$ & $3,0 \pm 0,17^{\mathrm{cII}}$ \\
\hline & MD+Inulin & $7,5 \pm 0,22$ & $1,1 \pm 0,05^{\text {agı }}$ & $2,7 \pm 0,18^{\mathrm{og} \mid}$ & $4,9 \pm 0,03^{\mathrm{cg} \mid}$ \\
\hline & $\mathrm{MD}+\mathrm{GOS}$ & $6,2 \pm 0,11$ & $1,3 \pm 0,02^{\text {anı }}$ & $2,9 \pm 0,08^{\mathrm{bn}}$ & $5,4 \pm 0,39^{\mathrm{cn}}$ \\
\hline L. plantarum & Sel bebas & $8,0 \pm 0,02$ & $2,6 \pm 0,39^{\text {aal }}$ & $4,4 \pm 0,23^{\text {Dal }}$ & $6,5 \pm 0,21^{\text {cal }}$ \\
\hline \multirow[t]{4}{*}{ BSL } & Maltodekstrin & $7,8 \pm 0,14$ & $0,3 \pm 0,02^{\text {ael }}$ & $1,9 \pm 0,31^{\text {bel }}$ & $2,9 \pm 0,14^{\text {cel }}$ \\
\hline & $\mathrm{MD}+\mathrm{Gum}$ Arab & $8,0 \pm 0,09$ & $0,8 \pm 0,02^{\text {aाı }}$ & $1,5 \pm 0,04^{\mathrm{DII}}$ & $2,9 \pm 0,97^{\mathrm{cII}}$ \\
\hline & MD+Inulin & $7,4 \pm 0,21$ & $1,1 \pm 0,29^{\mathrm{ag} ı}$ & $2,0 \pm 0,01^{\mathrm{pg} \mathrm{I}}$ & $3,8 \pm 0,24^{\mathrm{cg} I}$ \\
\hline & $\mathrm{MD}+\mathrm{GOS}$ & $6,9 \pm 0,42$ & $1,2 \pm 0,33^{\text {anı }}$ & $3,5 \pm 0,19^{\text {गгा }}$ & $5,4 \pm 0,35^{\mathrm{cпl}}$ \\
\hline
\end{tabular}

Keterangan: Angka-angka pada kolom yang sama yang diikuti oleh huruf yang sama (a) pada strain yang berbeda tidak berbeda nyata pada taraf uji $5 \%(P<0,05)$. Angka-angka pada kolom yang sama diikuti oleh huruf yang berbeda (b-e) berbeda nyata pada taraf uji $5 \%(P<0,05)$ pada bahan enkapsulan yang berbeda

Kedua strain probiotik yang dimikroenkapsulasi memberikan hasil ketahanan panas yang tidak berbeda nyata $(P<0,05)$ terhadap penurunan jumlah probiotik, sedangkan jenis bahan enkapsulan berpengaruh nyata $(P<0,05)$. Sintasan terbaik probiotik adalah pada suhu $50^{\circ} \mathrm{C}$ dengan penurunan jumlah sel probiotik yang dimikroenkapsulasi hanya berkisar antara 0,1-1,3 Log CFU mL $\mathrm{m}^{-1}$, sedangkan sel bebas mengalami penurunan yang lebih besar hinggal 2,6-2,9 Log CFU mL $\mathrm{mL}^{-1}$. Bahan enkapsulan yang paling baik yang mampu meningkatkan ketahanan sel terhadap panas adalah maltodekstrin pada kedua strain, dengan penurunan terendah pada suhu $50^{\circ} \mathrm{C}$ hanya sekitar 0,1 Log CFU mL ${ }^{-1}(L$. plantarum 2C12) dan 0,3 Log CFU $\mathrm{mL}^{-1}$ (L. plantarum BSL). Secara umum, semakin tinggi suhu pemaparan maka sintasan kedua strain juga semakin turun, baik untuk probiotik bebas maupun terenkapsulasi. Sel probiotik bebas dari kedua strain ternyata tidak mampu mempertahankan jumlah yang disyaratkan $\left(10^{6} \mathrm{CFU} \mathrm{mL}^{-1}\right)$ bahkan terhadap paparan suhu terendah $\left(50^{\circ} \mathrm{C}\right)$ (Gambar 1). Hasil dari probiotik terenkapsulasi memiliki perbedaan, dimana sintasan probiotik yang disyaratkan pada suhu $50^{\circ} \mathrm{C}$ dapat terpenuhi. Hal ini dapat dilihat dari sintasan probiotik terenkapsulasi lebih dari 6 Log CFU $\mathrm{mL}^{-1}$ pada suhu tersebut, dengan sintasan 6,5 sampai 7,6 Log CFU $\mathrm{mL}^{-1}$ pada L. plantarum $2 \mathrm{C} 12$ dan 6,5 sampai 7,5 Log CFU mL $\mathrm{m}^{-1}$ pada $L$. plantarum BSL.

\section{Pengaruh bahan enkapsulan terhadap ketahanan probiotik terenkapsula si pada $\mathrm{pH}$ rendah $(\mathrm{pH} \mathrm{2,0)}$ dan garam empedu $(0,5 \%)$}

Pengujian kemampuan sel bebas dan sel hasil mikroenkapsulasi terhadap $\mathrm{pH}$ rendah $(\mathrm{pH} 2,0)$ dan garam empedu (0,5\%) diperlukan untuk membandingkan kemampuan sel bebas dan sel hasil mikroenkapsulasi bertahan dalam sistem pencernaan. Ketahanan sel terhadap $\mathrm{pH}$ rendah atau garam empedu ditunjukkan dengan penurunan total sel setelah inkubasi dalam media yang mengandung asam $(\mathrm{pH} 2,0)$ atau garam empedu $(0,5 \%)$ selama 5 jam. Hasil pengujian ketahanan pada $\mathrm{pH}$ rendah $\mathrm{pH}$ 2) dan garam empedu dapat dilihat pada Gambar 2 dan Gambar 3. Gambar 2 menunjukkan sintasan kedua strain probiotik terhadap $\mathrm{pH}$ rendah $(\mathrm{pH} 2,0)$. Terjadi peningkatan kemampuan ketahanan sel probiotik terenkapsulasi dibandingkan sel probiotik bebas pada kondisi $\mathrm{pH}$ rendah $(\mathrm{pH} 2,0)$. Pada sel bebas, jumlah sel mengalami penurunan cukup besar yakni sebesar 2,6 Log CFU $\mathrm{mL}^{-1}$ pada $L$. plantarum 2C12 dan 2,1 Log CFU $\mathrm{mL}^{-1}$ pada $L$. plantarum BSL. Sintasan sel yang dimikroenkapsulasi mengalami peningkatan, yakni pada $L$. plantarum 2C12 sekitar 0,5 sampai 1,4 Log CFU mL ${ }^{1}$, dan pada $L$. plantarum BSL sekitar 0,5 sampai 1,6 Log CFU $\mathrm{mL}^{-1}$. Gambar 2 juga menunjukkan ketahanan kedua strain terhadap $\mathrm{pH}$ rendah $(\mathrm{pH}$ $2,0)$ tidak berbeda nyata $(P<0,05)$. Akan tetapi, jenis bahan enkapsulan berpengaruh nyata $(P<0,05)$ mampu melindungi probiotik pada kondisi $\mathrm{pH}$ rendah. Bahan enkapsulan yang menghasilkan proteksi yang paling baik adalah kombinasi bahan enkapsulan maltodekstrin dan GOS (5:1), dengan penurunan hanya sebesar $0,5 \log C F U \mathrm{~mL}^{-1}$ pada kedua strain.

Gambar 3 menunjukkan sintasan kedua strain probiotik karena perlakuan garam empedu (0,5\%). Mikroenkapsulasi meningkatkan ketahanan sel probiotik dibandingkan sel probiotik bebas terhadap garam empedu $(0,5 \%)$. 


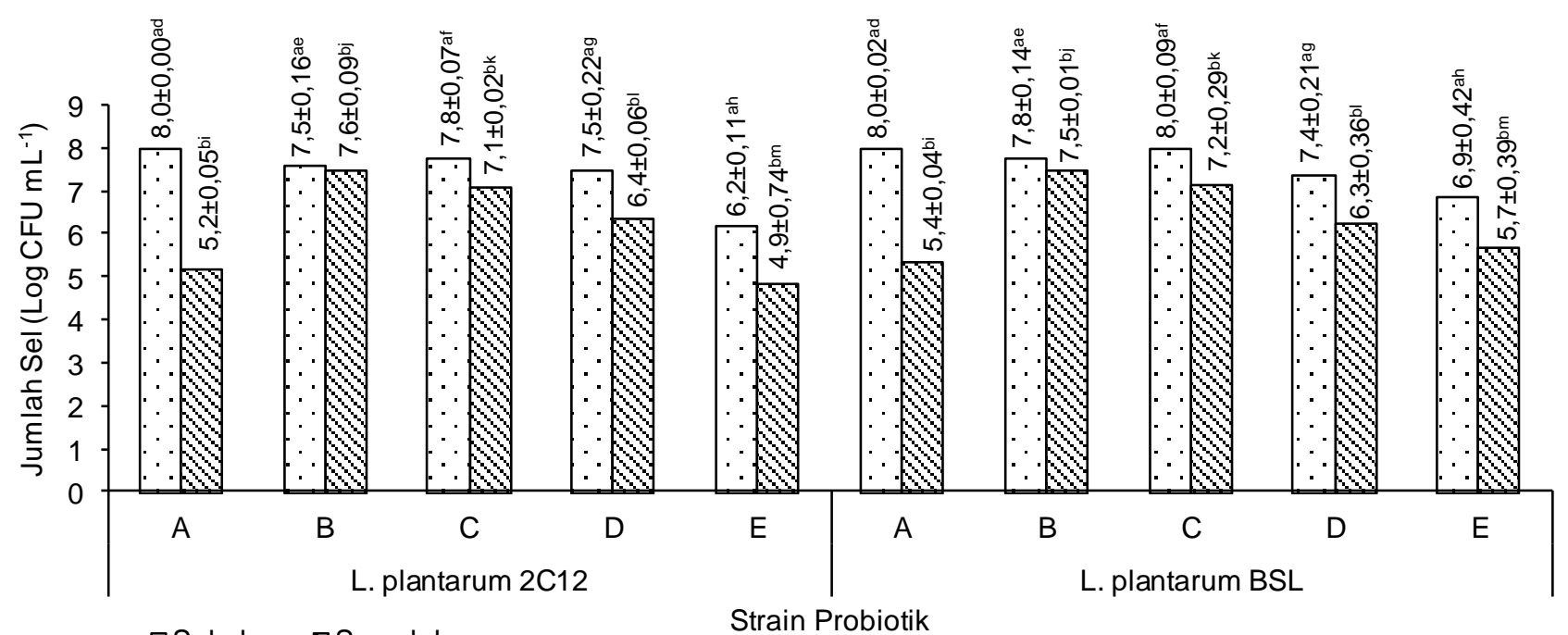

घSebelum $₫$ Sesudah

Gambar 1. Ketahanan sel probiotik terenkapsulasi terhadap perlakuan panas pada suhu $50^{\circ} \mathrm{C}$. A (Sel bebas tanpa mikroenkapsulasi), B (Maltodekstrin), C (Maltodekstrin + Gum Arab), D (Maltodekstrin + Inulin), E (Maltodekstrin + GOS). Batang histogram yang sama yang diikuti oleh huruf yang sama (a) tidak berbeda nyata $(P<0,05)$ pada strain yang berbeda. Batang histogram yang sama yang diikuti oleh huruf yang berbeda $(b-d)$ berbeda nyata $(P<0,05)$ pada bahan enkapsulan yang berbeda

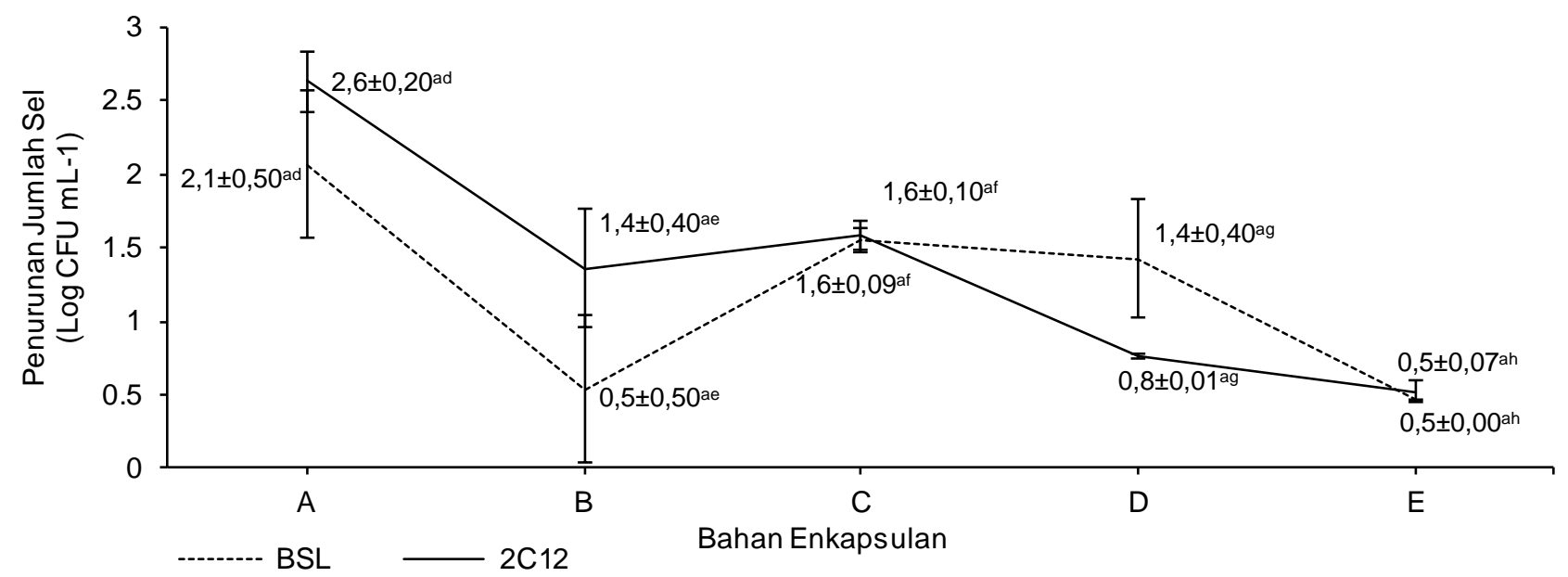

Gambar 2. Ketahanan sel probiotik terenkapsulasi terhadap $\mathrm{pH}$ rendah $(\mathrm{pH} 2,0)$. A (Sel bebas tanpa mikroenkapsulasi), B (Maltodekstrin), C (Maltodekstrin + Gum Arab), D (Maltodekstrin + Inulin), $E$ (Maltodekstrin + GOS). Batang histogram yang sama yang diikuti oleh huruf yang berbeda (b-d) berbeda nyata $(P<0,05)$ pada bahan enkapsulan berbeda. Batang histogram yang sama yang diikuti oleh huruf yang sama (a) tidak berbeda nyata $(P<0,05)$ pada strain yang berbeda

Pada sel bebas, jumlah sel mengalami penurunan cukup besar yakni sebesar $3,1 \mathrm{Log}$ CFU $\mathrm{mL}^{-1}$ pada L. plantarum $2 \mathrm{C} 12$ dan 2,9 Log CFU mL $\mathrm{mL}^{-1}$ pada L. plantarum BSL. Sintasan sel yang dimikroenkapsulasi mengalami peningkatan dengan penurunan jumlah sel yang lebih sedikit, yakni pada $L$. plantarum 2C12 sekitar 1,9 sampai 2,3 Log CFU mL ${ }^{1}$, dan pada L. plantarum BSL sekitar 1,5 sampai 2,5 Log CFU $\mathrm{mL}^{-1}$. Berdasarkan hasil analisis ragam, terlihat bahwa strain probiotik memberikan hasil yang tidak berbeda nyata $(P<0,05)$ terhadap ketahanan garam empedu, tetapi jenis bahan enkapsulan berpengaruh nyata $(P<0,05)$. Bahan enkapsulan yang menghasilkan proteksi yang paling baik adalah kombinasi bahan enkapsulan maltodekstrin dan GOS (5:1) pada strain L. plantarum 2C12, dan maltodekstrin pada strain $L$. plantarum BSL.

Ketahanan probiotik terhadap $\mathrm{pH}$ asam dan garam empedu lebih baik ketika sel dimikroenkapsulasi. Hal ini sesuai dengan penelitian Reddy et al. (2009) yang melaporkan maltodekstrin yang 
ditambahkan sebagai pembawa selama pengeringan semprot dapat mempertahankan viabilitas dan retensi sifat probiotik (L. plantarum CFR 2191, $L$. salivarius CFR 2158 dan Pediococcus acidilactici CFR 2193) terhadap asam dan toleransi empedu. Madhu et al. (2011) melaporkan L. fermentum memiliki ketahanan yang lebih baik secara signifikan terhadap $\mathrm{pH}$ asam dan garam empedu setelah dilakukan pengering semprot menggunakan maltodekstrin.

\section{Aktivitas antimikroba strain probiotik teren- kapsulasi}

Pengujian aktivitas antimikroba untuk mengetahui apakah proses mikroenkapsulasi menyebabkan perubahan sifat antimikroba probiotik. Aktivitas antimikroba diamati dengan menghitung peningkatan jumlah pertumbuhan E. coli ATCC 25922 ketika dikontakkan dengan probiotik pada media skim milk selama 24 jam. Hasil pertumbuhan E. coli ATCC 25922 dapat dilihat pada gambar 4 .

Gambar 4 menunjukkan probiotik yang ditambahkan (baik sel bebas maupun sel yang sebelumnya terenkapsulasi) mampu menghambat pertumbuhan sel $E$. coli sebanyak 1 Log CFU mL ${ }^{-1}$ dibandingkan kontrol, dimana kontrol adalah media skim milk yang hanya diinokulasi bakteri uji $E$. coli, tanpa penambahan probiotik. Pada kontrol, pertumbuhan $E$. coli sebanyak 4,3 Log CFU $\mathrm{mL}^{-1}$, sedangkan pada media skim milk yang ditambahkan dengan probiotik, baik yang bebas maupun yang dimikroenkapsulasi jumlah pertumbuhan $E$. coli sekitar 0,6 sampai 1,3 Log CFU $\mathrm{mL}^{1}$ lebih rendah pada kedua strain. BAL dikenal menghasilkan berbagai komponen antimikroba seperti asam organik (asam laktat dan asam asetat), hidrogen peroksida, etanol, diasetil, asetaldehid, asetoin, karbon dioksida, reuterin, reutericyclin dan bakteriosin (Suskovic et al., 2010). Lactobacillus plantarum 2C12 memiliki aktivitas antibakteri dan kemampuan koagregasi yang baik terhadap bakteri patogen (E. coli ATCC 25922, S. Typhimurium ATCC 14028, EPEC, dan $S$. aureus ATCC 25923) (Arief et al., 2015). Lactobacillus plantarum 2C12 juga mampu memproduksi bakteriosin (plantarisin). Bakteriosin yang dihasilkan dari isolat ini juga telah terbukti sebagai pengawet alami pada produk bakso (Arief et al., 2012). Isolat L. plantarum BSL memiliki aktivitas penghambatan yang tinggi terhadap Bacillus cereus, $S$. cereus dan E. coli (Kusumawati et al., 2003).

Hasil pengujian didapatkan aktivitas antimikroba probiotik (kecuali kontrol) terhadap E. coli ATCC 25922 menunjukkan hasil yang tidak berbeda nyata $(P<0,05)$ terhadap bakteri uji dan bahan enkapsulan. Hasil ini menunjukkan proses mikroenkapsulai tidak mengubah kemampuan aktivitas antimikroba sel probiotik. Golowczyc et al. (2011) melaporkan sel Lactobacillus spp. Yang dimikroenkapsulasi tidak mengubah ketahanan probiotik terhadap lisozim dan penisilin.

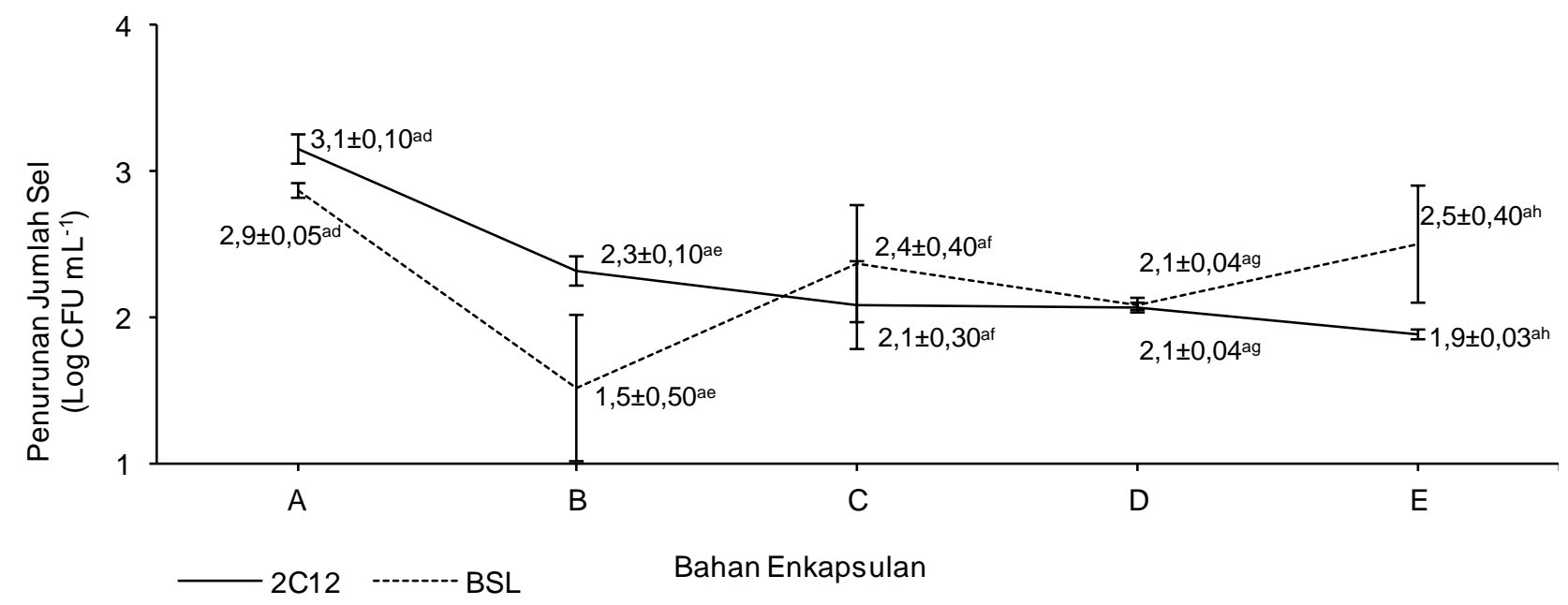

Gambar 3. Ketahanan sel probiotik terenkapsulasi terhadap garam empedu 0,5\%. A (Sel bebas tanpa mikroenkapsulasi), B (Maltodekstrin), C (Maltodekstrin + Gum Arab), D (Maltodekstrin + Inulin), $\mathrm{E}$ (Maltodekstrin + GOS). Batang histogram yang sama yang diikuti oleh huruf yang yang sama (a) tidak berbeda nyata $(P<0,05)$ pada strain berbeda. Batang histogram yang sama yang diikuti oleh huruf yang sama (b) tidak berbeda nyata $(P<0,05)$ pada bahan enkapsulan yang berbeda 


\section{L. plantarum 2C12}

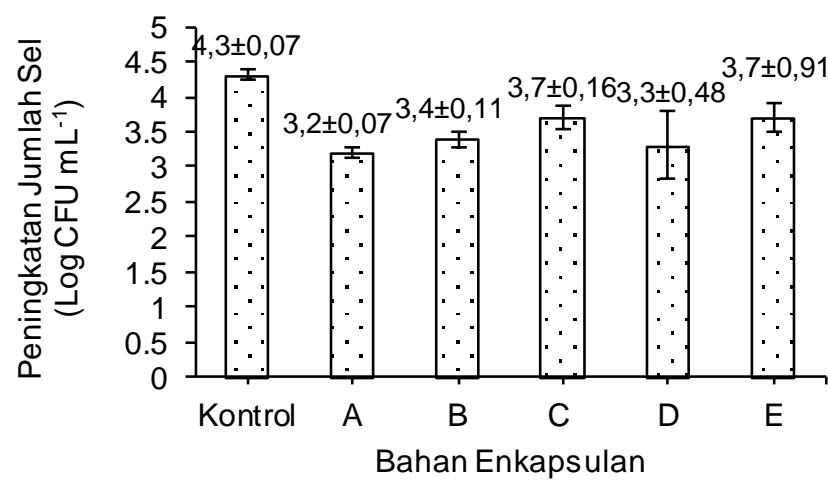

L. plantarum BSL

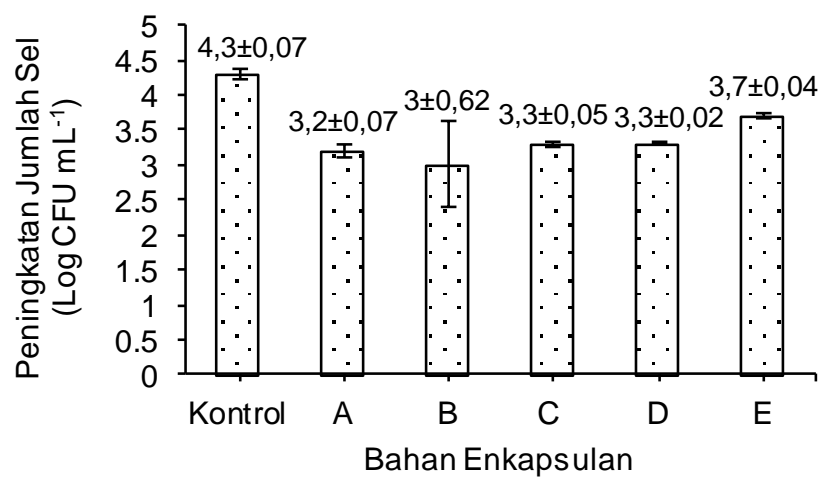

Gambar 4. Aktivitas antimikroba probiotik terhadap pertumbuhan E. coli. Kontrol (E. coli tanpa probiotik), A (Sel bebas tanpa mikroenkapsulasi), B (Maltodekstrin), C (Maltodekstrin + Gum Arab), D (Maltodekstrin + Inulin), E (Maltodekstrin + GOS)

\section{KESIMPULAN}

Proses mikroenkapsulasi dengan teknik pengering semprot menggunakan berbagai jenis enkapsulan mampu meningkatkan ketahanan sel probiotik L. plantarum $2 \mathrm{C} 12$ dan L. plantarum BSL terhadap panas $\left(50,60,70^{\circ} \mathrm{C}\right), \mathrm{pH}$ rendah $(\mathrm{pH} 2,0)$ dan garam empedu $(0,5 \%)$ serta tidak mempengaruhi aktivitas antimikroba terhadap $E$. coli. Bahan enkapsulan yang berbeda memberikan proteksi terhadap perlakuan tertentu yang berbeda pula pada kedua strain. Maltodekstrin memberikan proteksi terbaik pada panas, sedangkan kombinasi maltodekstrin dan GOS memberikan proteksi terbaik terhadap $\mathrm{pH}$ rendah untuk kedua strain. Hasil yang berbeda terlihat terhadap perlakuan terhadap garam empedu, pada strain L. plantarum BSL, enkapsulan terbaik adalah maltodekstrin, sedangkan pada $L$. plantarum 2C12 adalah kombinasi maltodekstrin dan GOS.

\section{UCAPAN TERIMAKASIH}

Peneliti mengucapkan terima kasih kepada Direktorat Penelitian dan Pengabdian kepada Masyarakat Direktorat Jenderal Pendidikan Tinggi Kementerian Pendidikan dan Kebudayaan melalui Hibah Kompetensi tahun 2014 yang telah membiayai penelitian ini.

\section{DAFTAR PUSTAKA}

Anekella K, Orsat V. 2013. Optimization of microencapsulation of probiotics in raspberry juice by spray drying. LWT-Food Sci Technol 50: 17-24. DOI: 10.1016/j.Iwt.2012.08.003.

Arief II, Jenie BSL, Suryati T, Ayuningtyas G, Fujiawan A. 2012. Antimicrobial activity of bacteriocin from indigenous Lactobacillus plantarum $2 \mathrm{C} 12$ and its application on beef meatball as biopreservative. J Indonesian Trop Anim Agric 37: 90-96.

Arief II, Jenie BSL, Astawan M, Fujiyama K, Witarto AB. 2015. Identification and probiotic characteristics of lactic acid bacteria isolated from Indonesian local beef. Asian J Animal Sci 9: 2536. DOI: 10.3923/ajas.2015.25.36.

Borgogna M, Bellich B, Zorzin L, Lapasin R, Cesàro A. 2010. Food microencapsulation of bioactive compounds: rheological and thermal characterisation of non-conventional gelling system. Food Chem 122: 416-423. DOI: 10.1016/j. foodchem.2009.07.043.

[FAO/WHO] Food and Agriculture Organization/ World Health Organization. 2006. Probiotics in food. Health and Nutritional Properties and Guidelines for Evaluation. Rome, Italy: FAO Food and Nutrition Paper No. 85.

Golowczyc M, Silva J, Abraham A, Deantoni G, Teixeira P. 2011. Cellular injuries of spray dried Lactobacillus spp. isolated from kefir and their impact on probiotic properties. Int $\mathrm{J}$ Food Microbiol 144: 556-560. DOI: 10.1016/j. ijfood micro.2010.11.005.

Harmayani E, Ngatirah, Rahayu ES, Utami T. 2001. Ketahanan dan viabilitas probiotik bakteri asam laktat selama proses pembuatan kultur kering dengan metode freeze dan spray drying. J Teknol Industri Pangan 9: 126-132.

Hernández-Carranza $P$, López-Mal A, JiménezMunguía M. 2014. Microencapsulation quality and efficiency of Lactobacillus casei by spray drying using maltodextrin and vegetable extracts. J Food Res 3: 61-69. DOI: 10.5539/ jfr. $3 n 1 p 61$. 
Kusumawati N, Jenie BSL, Setyahadi S, Hariyadi RD. 2003. Seleksi bakteri asam laktat indigenus sebagai galur probiotik dengan kemampuan menurunkan kolesterol. Microb Indonesia 8: 39 43.

Liu Z, Zhou J, Zeng Y, Ouyang X 2004. The enhancement and encapsulation of Agaricus bisporus flavor. J Food Eng 65: 391-396. DOI: 10.1016/j.jfoodeng.2004.01.038.

Mandal S, Puniya AK, Singh K. 2006. Effect of alginate concentration on survival of microencapsulated Lactobacillus casei NCDC 298. Int Dairy J 16: 1190-1195. DOI: 10.1016/j.idairyj. 2005.10.005.

Madhu AN, Awasthi SP, Reddy KBPK, Prapulla SG. 2011. Impact of freeze and spray drying on the retention of probotic properties of Lactobacillus fermentum: an in vitro evaluation model. Int $\mathrm{J}$ Microbiol Res 2: 243-251.

Manojlović V, Nedovic V, Kailas apathy K, Zuidam N. 2010. Encapsulation of Probiotics for use in Food Products. In: Encapsulation Technologies for Active Food Ingredients and Food Processing. 269-302. Zuidam NJ, Nedovic VA (eds.). Springer, New York, USA. 269-302.

Mortazavian N, Razavi SH, Ehsani M, Sohrabvandi S. 2007. Principles and methods of microencapsulation of probiotic microorganismms. Iranian J Biotechnol 5: 1-18.

Nualkaekul S, Deepika G, Charalampopoulos D. 2012. Survival of freeze dried Lactobacillus plantarum in instant fruit powders and reconstituted fruit juices. Food Res Int 48: 627633. DOI: 10.1016/j.foodres.2012.06.00 3.
Nuraida L Hana, Hartanti AW, Prangdimurti E. $2012^{a}$. Potensi Lactobacillus yang diisolasi dari air susu ibu untuk mencegah diare. J Teknol Industri Pangan 23: 158-164. DOI: 10.6066/jtip. 2012.23.2.158.

Nuraida L Susanti, Palupi NS, Hana, Bastomi RR, Priscilla D, Nurjana S. $2012^{b}$. Evaluation of probiotics properties of lactic acid bacteria isolated from breast milk and their potency as starter culture for yoghurt fermentation. Int $\mathrm{J}$ Food Nutr Public Health 5: 33-60.

Osorio C, Forero DP, Carriazo JG. 2011. Characterisation and performance assessment of guava (Psidium guajava L.) microencapsulates obtained by spray-drying. Food Res Int 44: 1174-1181. DOI: 10.1016/j.foodres.2010. 09.007 .

Reddy KBPK, Madhu AN, Prapulla SG. 2009. Comparative survival and evaluation of functional probiotic properties of spray-dried lactic acid bacteria. Int J Dairy Technol 62: 240248. DOI: 10.1111/j.1471-0307.2009.004 80.x.

Saad N, Delattre C, Urdaci M, Schmitter JM, Bressollier P. 2013. An overview of the last advances in probiotic and prebiotic field. LWTFood Sci Technol 50: 1-16. DOI: 10.1016/j.Iwt. 2012.05.014.

Suskovic J, Kos B, Beganovic J, Pavunc AL, Habjanic K, Matosic S. 2010. Review: Antimicrobial activity the most important property of probiotic and starter lactic acid bacteria. Food Technol Biotechnol 48: 296-307. 